NBER WORKING PAPER SERIES

\title{
THE OUTPUT CONTRIBUTIONS OF \\ COMPUTER EQUTPMENT AND \\ PERSONNEL: A FIRM-LEVEL ANALYSIS
}

Frank R. Lichtenberg

Working Paper No. 4540

\section{NATIONAL BUREAU OF ECONOMIC RESEARCH 1050 Massachusetts Avenue \\ Cambridge, MA 02138}

November, 1993

I am grateful to the Alfred P. Sloan Foundation for financial support to Scout Liebs of Informationweek and Michael Sullivan-Trainor of Computerworld for providing me with data: to Michael Van Biema for helpful comments and assistance; and to Benedicte Reyes for capable research assistance. I am responsible for any errors. This research was conducted under the auspices of Columbia Business School's Center for Productivity and Technology. This paper is part of NBER's research program in Productivity. Any opinions expressed are those of the author and not those of the National Bureau of Economic Research. 


\section{THE OUTPUT CONTRIBUTIONS OF \\ COMPUTER EQUIPMENT AND \\ PERSONNEL: A FIRM-LEVEL ANALYSIS}

\section{ABSTRACT}

This paper examines the output contributions of capital and labor deployed in information systems (IS) at the firm level during the period 1988-91 throughout the business sector, using two different sources of data on these inputs. Our production function estimates suggest that there are substantial excess retums to both IS capital and IS labor, although the size and significance of the excess returns to IS eapital is larger. Computer capital and labor jointly contribute, or account for, about 21 percent of output, although only about $10 \%$ of both capital and labor income accrue to IS factors. Although IS employees accounted for a very small share of total employment by 1986 , IS employment growth is estimated to have made a larger contribution to 1976-86 output growth than non-1S employment, due to the very rapid growth (16\% per annum) of IS employment. The estimated marginal rate of substitution (MRS) between IS and non-IS employees, evaluated at the sample mean, is 6 : one IS employee can be substituted for six non-IS employees without affecting output.

\section{Frank R. Lichtenberg}

Columbia Business School

726 Uris Hall

New York, NY 10027

and NBER 


\section{Introduction}

In the last few years there have been several studies of the contribution of computers to output. Lau and Tokutsu (1992) investigated this issue at the aggregate level using U.S. annual time-series data for the period 1960-90. Berndt, Morrison, and Rosenblum (1992), Morrison and Berndt (1991), and Siegel and Griliches (1992) studied it at the industry level. We are familiar with only one major firm-level study, by Brynjolfsson and Hitt (1993).

Two of the industry-level studies concluded that computers have had a negative influence on productivity. Berndt, Morrison, and Rosenblum (1992) constructed an estimate of the ratio of an industry's "high-tech" capital stock (consisting of computers, communication equipment, scientific instruments, and photocopy equipment) to its total capital stock for 2-digit manufacturing industries for the period 1968-86. They found that changes in this ratio were negatively correlated with labor productivity growth. Using similar data but a different methodology, Morrison and Berndt (1991) concluded that "in 1986, estimated marginal benefits of investments in ["high-tech" office and information technology equipment] are less than marginal costs, implying over investment in" this capital in 1986.

The other studies have reached the opposite conclusion. Lau and Tokutsu (1992) found that "computer technology has 
made a very significant contribution to the growth of aggregate real output in the U.S. economy during the past three decades. In fact, approximately 50 percent of the growth of aggregate real output during this period can be attributed to the growth in computer capital" (p. 25). Siegel and Griliches (1992, p. 456) found a strong "positive correlation between productivity growth (but not acceleration in productivity) and investment in computers." Brynjolfsson and Hitt (1993) also conclude that computers "have made a substantial and significantly significant contribution to output." 1

All of these studies have been useful, and have increased our understanding of the role of computers in production, but they are subject to various limitations. For example, 1982 was the last year of the period analyzed by Siegel and Griliches; according to Baily and Gordon (1988, p. 390) this preceded the

1 Because economists believe that an employee's wage is positively correlated with his or her productivity, estimates of the relationship between computer use and wage rates may provide indirect evidence about the productivity impact of computers. These estimates also suggest that the productivity impact has been positive. Using data from the Current Population Survey and the High School and Beyond Survey, Krueger found (1993, p. 33) that

"workers who use computers on their job earn 10 to 15 percent higher wages." Berman, Bound, and Griliches (1993) also found strong positive correlations between skill upgrading and increased investment in computers within industries. 
era of great diffusion of computers. ${ }^{2}$ The industry-level studies were based on the manufacturing sector; as Baily and Gordon (1988, p. 389) point out, "the manufacturing sector is not a big owner of the electronic equipment it produces." The studies that have found that computer investment yields positive returns have not provided valid tests of the (stronger) hypothesis that computer investment (like R\&D investment) yields excess returns--returns greater than those earned by other factors. In addition, although labor costs account for over $40 \%$ of information systems (IS) budgets, only one previous study has examined the role of IS labor as well as IS capital.

In this paper we examine the output contributions of both IS capital and IS labor at the firm level during the period 198891 throughout the business sector, using two different sources of data on these inputs: Informationweek magazine and Computerworld magazine. The use of two independent data sources allows us to explore the reliability of the data on IS budgets, capital and labor.

In Section 2 we postulate a production function that

2 Baily and Gordon show that computers and communication equipment as a percent of total non-residential capital employed in nonmanufacturing increased from $4.4 \%$ in $1960-69$ to $6.7 \%$ in $1970-79$ to $16.2 \%$ in 1987. Similarly, Krueger (1993, p. 36) reports that the percent of workers who directly use a computer at work increased from $24.6 \%$ in 1984 to $37.4 \%$ in 1989 . 
incorporates IS capital (and labor) in addition to non-IS inputs, and discuss the restrictions imposed on the parameters of this function by several hypotheses. In Section 3 we review in greater detail the empirical results obtained by Lau and Tokutsu and by Brynjolfsson and Hitt. We describe our research design for estimating the production function in Section 4, and the data sources in Section 5. Summary statistics, including some basic facts about the allocation of information technology resources, are presented in Table 6. Estimates of the production function and their interpretation are discussed in Section 7. Section 8 contains a summary and concluding remarks.

2. Incorporating computer capital (and labor) in the production function

The major objective of this and previous studies in this area is to estimate (and test hypotheses about) the marginal product of computer capital, or a related parameter, the output elasticity of computer capital. Let us postulate the following production function :

$$
\ln \mathrm{Y}=\alpha_{1} \ln \mathrm{K}_{1}+\alpha_{0} \ln \mathrm{K}_{0}+\beta \ln \mathrm{L}
$$

where $\mathrm{Y}=$ output, $\mathrm{K}_{1}=$ computer capital stock, $\mathrm{K}_{0} \equiv \mathrm{K}-\mathrm{K}_{1}$ $=$ non-computer capital stock, $\mathrm{K}=$ total capital stock, and $\mathrm{L}=$ labor.

$\alpha_{1}=\mathrm{d} \ln \mathrm{Y} / \mathrm{d} \ln \mathrm{K}_{1}=\left(\mathrm{d} \mathrm{Y} / \mathrm{d} \mathrm{K} \mathrm{K}_{1}\right)\left(\mathrm{K}_{\mathrm{I}} / \mathrm{Y}\right)=\mathrm{MP}_{1}\left(\mathrm{~K}_{1} / \mathrm{Y}\right)$, 
where $\mathrm{MP}_{1} \equiv\left(\mathrm{d} \mathrm{Y} / \mathrm{d} \mathrm{K}_{\mathrm{i}}\right)=$ the marginal product of computer capital.

There are at least two different ("null") hypotheses that one might want to test concerning $\alpha_{1}$. The first is $\mathrm{H}_{0}: \alpha_{1} \leq 0$ against the alternative that $\alpha_{1}>0$. In other words, one could test whether or not the output elasticity (and marginal product) of computer capital is positive. The second null hypothesis is that $M P_{1} / M_{0} \leq R_{1} / R_{0}$ : the ratio of the marginal products of computer and non-computer capital is less than the ratio of their rental prices $\left(R_{i}=\right.$ the rental price of asset $\left.i\right)$. This hypothesis can be expressed in the form

$$
\mathrm{H}_{0}: \alpha_{1}-\left(\mathrm{R}_{1} \mathrm{~K}_{1} / \mathrm{R}_{0} \mathrm{~K}_{0}\right) \alpha_{0} \leq 0
$$

Since the second term on the left-hand-side of eq. (2) is positive, rejection of this hypothesis is "stronger" than rejection of the first hypothesis. Rejection of it implies not just that there are positive returns to computer investment, but that there are excess returns to computer investment.

Much previous research has shown that capital (and labor) employed in research and development (R\&D) activities has a higher marginal product than other capital employed by the firm: there appear to be "excess" private returns to R\&D investment. Rejection of the hypothesis represented by eq. (2) would imply that like R\&D expenditure, IS expenditure yields excess returns. As Lau and Tokutsu (1992) observe, in equilibrium the 
rental price of asset $\mathrm{i}(\mathrm{i}=0,1)$ is

$$
R_{i}=P_{i}\left(R+\delta_{i}-E\left(p_{i}\right)\right),
$$

where $P_{i}$ the purchase price of asset $i$ (the "asset price"), $R=$ the nominal interest rate, $\delta_{\mathrm{i}}=$ the depreciation rate of asset $\mathrm{i}$, and $E\left(p_{j}\right)=$ the expected rate of capital gains on asset $i\left(p_{i} \equiv\left(P_{i+1}-\right.\right.$ $\left.P_{j}\right) / P_{i}$ ). Hence the ratio $r_{i}$ of the rental price to the asset price is

$$
\mathrm{r}_{\mathrm{i}} \equiv \mathrm{R}_{\mathrm{i}} / \mathrm{P}_{\mathrm{i}}=\left(\mathrm{R}+\delta_{\mathrm{i}}-\mathrm{E}\left(\mathrm{p}_{\mathrm{i}}\right)\right)
$$

Hence the hypothesis (2) may be rewritten as

$$
\mathrm{H}_{0}: \alpha_{1}-\left(\mathrm{r}_{1} / \mathrm{r}_{0}\right)\left(\mathrm{P}_{1} \mathrm{~K}_{1} / \mathrm{P}_{0} \mathrm{~K}_{0}\right) \alpha_{0}>0
$$

According to Lau and Tokutsu, reasonable estimates of the mean values during $1960-90$ of the variables on the right-hand-side of equation (3) are as follows: $\mathrm{R}=.07, \delta_{1}=.20, \delta_{0}=.05, \mathrm{E}\left(\mathrm{p}_{1}\right)$ $=-.15, \mathrm{E}\left(\mathrm{p}_{0}\right)=.05$. Computers depreciate more rapidly than other capital, and the purchase price of computers has declined rapidly, whereas the purchase price of other capital has increased. Hence $r_{1}=.42, r_{0}=.07,\left(r_{1} / r_{0}\right)=6$, and eq. (4) becomes

$$
\mathrm{H}_{0}: \alpha_{1}-6\left(\mathrm{P}_{1} \mathrm{~K}_{1} / \mathrm{P}_{0} \mathrm{~K}_{0}\right) \alpha_{0}>0
$$

Lau and Tokutsu (1992) and Brynjolfsson and Hitt (1993) both obtained estimates of the parameters $\alpha_{1}$ and $\alpha_{0}$, but they did not perform tests of the hypothesis (5). Lau and Tokutsu did not perform tests on any linear combinations of the two parameters. Brynjolfsson and Hitt did attempt to compare $\alpha_{1}$ to $\alpha_{0}$ to 
determine whether the "return on investment" in both types of capital was the same, but their test was based on the difference $\alpha_{1}-\left(\mathrm{P}_{1} \mathrm{~K}_{1} / \mathrm{P}_{0} \mathrm{~K}_{0}\right) \alpha_{0}$ rather than $\alpha_{1}-6\left(\mathrm{P}_{1} \mathrm{~K}_{1} / \mathrm{P}_{0} \mathrm{~K}_{0}\right) \alpha_{0}$ : it failed to adjust for the much higher (by a factor of six) ratio of rental- to purchase-price for computers. It therefore overestimated the "excess returns" to computer investment.

Our data indicate that labor costs account for over 40 percent of information systems (IS) budgets, and provide estimates at the firm level of the number of IS employees. It is therefore natural to generalize the production function (1) as follows:

$$
\ln \mathrm{Y}=\alpha_{1} \ln \mathrm{K}_{1}+\alpha_{0} \ln \mathrm{K}_{0}+\beta_{1} \ln \mathrm{L}_{1}+\beta_{0} \ln \mathrm{L}_{0}(6)
$$

where $L_{1}=$ the number of computer (IS) employees, and $L_{0} \equiv$ $L-L_{1}=$ the number of other employees.

There are two hypotheses that one might want to test about $\beta_{1}$. The first is that the ratio of the marginal product to the wage rate is higher for IS employees than it is for other employees; this may be expressed as

$$
\mathrm{H}_{0}: \beta_{1}-\left(\mathrm{W}_{1} / \mathrm{W}_{0}\right)\left(\mathrm{L}_{1} / \mathrm{L}_{0}\right) \beta_{0}>0
$$

where $W_{i}(i=0,1)=$ the wage rate of type $i$ employees. The second hypothesis is that the ratio of computer labor to computer capital output elasticities is equal to the ratio of their shares in the IS budget:

$$
\mathrm{H}_{0}: \beta_{1}-\left(\mathrm{W}_{1} / \mathrm{R}_{1}\right)\left(\mathrm{L}_{1} / \mathrm{K}_{1}\right) \alpha_{1}=0
$$




\section{$\underline{\text { 3. Previous research }}$}

Lau and Tokutsu (1992) estimated a translog unit cost function with three inputs (computer capital, non-computer capital, and labor) from aggregate U.S. time-series data. (They did not distinguish between computer and non-computer labor.) They were unable to reject the hypothesis of a stationary (no technical progress) Cobb-Douglas unit cost function. They estimated a cost function rather than a production function because at the aggregate level "it is difficult to separate computer capital and non-computer capital." The aggregate production function implied by their cost function estimates is as follows:

$$
\ln \mathrm{Y}=.072 \ln \mathrm{K}_{1}+.329 \ln \mathrm{K}_{0}+.599 \ln \mathrm{L}
$$

where $\mathrm{Y}=$ output, $\mathrm{K}_{1}=$ computer capital stock, $\mathrm{K}_{0}=$ noncomputer capital stock, and $\mathrm{L}=$ labor. The average annual growth rates during $1961-90$ of $\mathrm{Y}, \mathrm{K}_{1}, \mathrm{~K}_{0}$, and $\mathrm{L}$ were $3.1 \%$, $21.5 \%, 1.4 \%$, and $1.8 \%$, respectively. (According to NSF, $\mathrm{L}_{1}-$ "computer specialists employed in industry"--increased at an average annual rate of $16.2 \%$ between 1976 and 1986.) Hence approximately one-half of the growth in aggregate output is attributable to the growth in computer capital.

Brynjolfsson and Hitt (1993) examined the role of IS labor as well as IS capital in production using longitudinal data on several hundred large American companies for the period 1987- 
91. They estimated production functions using the following specification and variable definitions:

$$
\begin{array}{r}
\ln Y=a_{1} \ln K_{1}+a_{0} \ln K_{0}+b_{1} \ln \left(W_{1} L_{1}\right) \\
+b_{0} \ln \left(\operatorname{COGS}-W_{1} L_{1}\right)
\end{array}
$$

where COGS $=$ cost of goods sold (total labor, materials, and other non-interest expenses). . Their measure of computer labor was $W_{1} L_{1}$ (IS budget labor expense) rather than the number of IS employees $L_{1}$, perhaps because $L_{1}$ was available only in a single year (1990). Our data suggest that there is substantial variation in this sample in the implicit annual wage rate of IS employees $\left(W_{1}\right)$ : it ranges from about $\$ 9000$ to $\$ 135,000$. Although some of this variation may reflect differences in labor quality, skill, and hours of work, it may also reflect substantial measurement error. We will use IS employment rather than the IS wage bill as our measure of computer labor. Because the last regressor in eq. (9) includes--in a rather unconventional way-expenditures on materials as well as on non-IS labor--this specification does not permit comparison of the marginal productivity of IS employees to that of other workers.

Brynjolfsson and Hitt report estimates of a large number of variants of eq. (9); a typical set of estimates, based on a sample of both manufacturing and service firms, is as follows $(\mathrm{N}$ $=1055, \mathrm{t}$-statistics in parentheses):

$$
\ln \mathrm{Y}=\underset{(2.12)}{.0061} \ln \mathrm{K}_{1}+.0462 \ln \mathrm{K}_{0}+.0274 \ln \left(\mathrm{W}_{1} \mathrm{~L}_{1}\right)
$$


The coefficients on IS capital and IS labor are both positive and significant. The computer capital elasticity, .0061, is $13 \%$ as large as the non-computer capital elasticity. This is larger than the imputed ratio of $\mathrm{K}_{1}$ rental payments to $\mathrm{K}_{0}$ rental payments (= $\left.6 *\left(\mathrm{P}_{1} \mathrm{~K}_{1} / \mathrm{P}_{0} \mathrm{~K}_{0}\right)=6 * .014=8.5 \%\right)$--implying excess returns to computer capital--but the difference between the elasticity ratio and the rental payment ratio may not be significant. Moreover, the finding that the coefficient on IS labor is over four times as large as the coefficient on IS capital is anomalous, since firms apparently spend more on IS capital.

\section{Research design}

Our objective is to estimate production functions of the form

$$
\ln \mathrm{Y}=\alpha_{1} \ln \mathrm{K}_{1}+\alpha_{0} \ln \mathrm{K}_{0}+\beta_{1} \ln \mathrm{L}_{1}+\beta_{0} \ln \mathrm{L}_{0}(11)
$$
using longitudinal, firm-level data. Although at the firm level, purchases of intermediate materials account for a substantial fraction of total costs (about $50 \%$ in manufacturing), due to lack of data materials are not included as an input in eq. (11). Y should therefore be interpreted as real value added. We do not actually observe real value added, however; instead we observe 
nominal gross output, or revenue (R). $R$ is related to $Y$ by

$$
\mathrm{R}=\mathrm{P}(\mathrm{Z} / \mathrm{Y}) \mathrm{Y}=\mathbf{P} \pi \mathrm{Y}
$$

where $P=$ (gross) output price, $Z=$ real gross output, and $\pi \equiv$ $\mathrm{Z} / \mathrm{Y}=$ the ratio of real gross output to real value added. We observe a sample of firms (indexed by i) in a variety of industries (indexed by $j$ ) over a period of years (indexed by $t$ ). $R_{i j t}$ denotes nominal revenue of firm $i$ in industry $j$ in year $t$, for example. Suppose that $P$ and $\pi$ vary across industries and years, but are invariant within industries and years; in particular, suppose that $\ln \left(P_{i j t} \pi_{i j j}\right)=\theta_{j}+\delta_{i}{ }^{3}$. Then the relationship between revenue and capital and labor inputs may be expressed as follows:

$$
\begin{aligned}
& \ln \mathrm{R}_{\mathrm{ijt}}=\alpha_{1} \ln \mathrm{K}_{1, \mathrm{jit}}+\alpha_{0} \ln \mathrm{K}_{0, \mathrm{ji}} \\
& +\beta_{\mathrm{i}} \ln \mathrm{L}_{\mathrm{i}, \mathrm{ji} t}+\beta_{0} \ln \mathrm{L}_{0, \mathrm{ijt}}+\theta_{\mathrm{j}}+\delta_{\mathrm{t}}
\end{aligned}
$$

Under these assumptions, the coefficients from the real-valueadded production function (11) may be identified from a grossrevenue regression that includes industry and year dummies.

An obvious advantage of this cross-sectional, withinindustry research design is that it enables us to finesse the extremely difficult--particularly in the service sector--problem of price (and real output) measurement. ${ }^{4}$ Our procedure does not

${ }^{3}$ Inclusion of a complete set of industry/year interaction effects would consume too many degrees of freedom. (1992).

See Lichtenberg and Griliches (1989), and Griliches 
require us to have accurate output or input deflators, provided only that these deflators are invariant across firms within industries and years, an assumption which does not appear to trouble most economists.

\section{Data sources}

We utilize two different sources of data on computer capital and labor, $\mathrm{K}_{1}$ and $\mathrm{L}_{1}$. The first is the same source used by Brynfolfsson and Hitt, the annual survey of chief information systems executives conducted by International Data Group, a subset of which is published in Computerworld magazine. This survey provides data on the following variables:

IS Budget $\left(\approx \mathrm{R}_{1} \mathrm{~K}_{1}+\mathrm{W}_{1} \mathrm{~L}_{1}\right)$ : Corporatewide capital and operating budget for information systems and services. Expenditures for staff, hardware, software, and data communications are excluded. Not included are telecommunications costs or spending on information technology by departments other than IS.

$\%$ of IS Budget for staff

$\%$ of IS Budget for training 
Market value of processors $\left(\approx P_{1} K_{1}\right)$ : the current market value of all major processors, including supercomputers, mainframes, and minicomputers. They reflect the dollar value of the systems if they were sold on the market today, regardless of whether the company owns or leases the systems.

\section{Total IS Staff $\left(L_{1}\right)$ (1990 and 1992 only)}

Informationweek magazine was the second source of data. Like Computerworld, Informationweek has conducted an annual survey since 1989 of companies' IS budgets and staff. (The IS Staff data are now avaiable for each of the five years 1989-93.) Informationweek also reports rankings of companies by the total estimated value in the used equipment market of their installed computer base, including storage and communications devices. This estimate is developed by Computer Intelligence Corp., a market research company that surveys about 30 thousand "sites" (e.g., individual departments of companies) per month to construct these estimates. The Computerworld estimate of the market value of processors may not be based on such detailed research, and may therefore be less reliable.

Unfortunately, in the Informationweek data companies are simply ranked and grouped into broad ranges of computer asset 
value (e.g. over $\$ 200 \mathrm{~m}$., $\$ 100-\$ 200 \mathrm{~m}$., $\$ 50-\$ 100 \mathrm{~m}$, etc.); actual asset values are not reported. However we obtained estimates (which we believe are fairly precise) of this value by interpolating the published data. In 1992, for example, there were 47 firms (ranked 12 to 58) whose computer asset value was between $\$ 100 \mathrm{~m}$. and $\$ 200 \mathrm{~m}$. We assumed that the highestand lowest-ranked firms were at the top and bottom of this range, respectively, and that the other firms were equally spaced within this range, i.e. we assigned an asset value (V) based on rank (RANK) using the formula $V=200-[($ RANK - 12) / 46] 100. (This procedure could not be applied to 10 to 15 firms per year in the top, open-ended asset value category.)

As noted earlier, the noncomputer capital stock is defined as the total capital stock minus the computer capital stock: $\mathrm{K}_{0} \equiv$ $\mathrm{K}-\mathrm{K}_{1}$. We defined $\mathrm{K}$ as the book value of total net property, plant, and equipment: the (historic) cost of tangible fixed property used in the production of revenue, less accumulated depreciation (annual data item $\# 8$ in the Compustat Industrial File). This is an imperfect measure of capital for two reasons: it is based on historic rather than replacement cost (i.e. it fails to account for changes in asset prices), and on accounting rather than economic depreciation. To the extent that the ratio of historic to replacement cost and the ratio of accounting to economic depreciation are constant across firms within industries 
and years, however, inclusion of the industry and year dummies will eliminate biases arising from this definition of $K$ (hence $K_{0}$ ).

Non computer labor input $\left(\mathrm{L}_{0}\right)$ was defined as total employment (L) minus the number of IS employees.

Computerworld survey data were available for the years 1988-92, and Informationweek survey data were available for the years 1988-93. Unfortunately, Compustat data on total assets (PPE) were not available for most firms after 1991, so our production function estimates are based only on data up to that year. Moreover, data on $L_{1}$ for a substantial number of firms became available only beginning in 1990 , so production functions in which total employment is disaggregated into $\mathrm{L}_{1}$ and $\mathrm{L}_{0}$ are (at most) primarily based on data for 1990 and 1991. Also, Informationweek (the only source that attempts to collect $L_{1}$ data annually) is sometimes unable to obtain current information on $\mathrm{L}_{1}$, so it simply assigns the previous year's number.

The shortness of the time series for each firm, and the occasional imputation of lagged values for missing data, lead one to expect that ("within") estimation of production functions with fixed "firm effects" would not yield reasonable or reliable estimates. We found this to be the case, and do not report such estimates in this paper. In the near future, however, we plan to extend the sample in the time dimension to enable full exploitation of the longitudinal character of the data. 
6. Summary statistics

Summary statistics based on the Informationweek data are reported in Table 1. In 1993, the average IS budget was $\$ 177$ million. The weighted (by sales) average ratio of ISBUD to sales was $2.7 \%$. The nominal IS budget fell about 10 percent between 1990 and 1993, but sales fell by about the same magnitude (reflecting the recession and slow recovery), so the ratio of IS spending to sales remained roughly constant. ${ }^{5}$

The mean number of IS employees was 1121 in 1993, also down about 10 percent from the 1990 figure. However total employment declined less than IS employment, so that weightedaverage $\left(\mathrm{L}_{\mathrm{I}} / \mathrm{L}\right)$ declined from $3.3 \%$ to $2.9 \%$. The fact that the weighted average value of $\left(\mathrm{L}_{1} / \mathrm{L}\right)$ is always lower than the unweighted average indicates that $\left(\mathrm{L}_{1} / \mathrm{L}\right)$ tends to be inversely related to total employment. This might be a reflection of economies of scale.

5 In 1992 Informationweek for the first time published IS spending and capital value data for the top 50 (ranked by value of IS capital) European companies. IS spending and capital value of these firms appears to be much greater than those of the top 50 American firms. The unweighted mean ratio of IS expenditure to sales was $3.7 \%$ for Europe and $2.2 \%$ for the U.S.; the t-statistic on this difference was 2.1 (p-value $=.04$ ). Moreover, the value of the IS capital employed by each of the 50 European firms was over $\$ 400 \mathrm{~m}$., whereas only 11 of the U.S. companies had IS capital whose value was at least $\$ 250$ million. 
On average during the sample period, then, the number of IS employees was about $3.2 \%$ as large as the number of other employees. To perform the appropriate hypothesis tests, we need to multiply this ratio by the ratio of IS to non-IS employee wage rates $\left(W_{1} / W_{0}\right)$, to obtain an estimate of relative (IS to non-IS) labor costs. In 1990, the average annual earnings of all privatesector workers (a weighted average of $\mathrm{W}_{1}$ and $\mathrm{W}_{0}$ ) was $\$ 17,994 .^{6}$ The Computerworld data indicate that in 1990 , IS labor cost per employee was $\$ 56,091$. This is likely to be an overestimate of $\mathrm{W}_{1}$, since it includes fringe benefits. (According to the National Science Foundation, the average annual salary in 1986--the most recent year for which data are available--of "computer specialists employed in industry" was $\$ 37,900$.) Adopting this estimate implies that $\mathrm{W}_{0}=\$ 16,735, \mathrm{~W}_{1} / \mathrm{W}_{0}=$ 3.35 , and $\mathrm{L}_{1} \mathrm{~W}_{1} / \mathrm{L}_{0} \mathrm{~W}_{0}=10.7 \%$. The ratio of IS to non-IS labor costs is no more than $10.7 \%$, and probably less. To perform hypothesis tests, we assume that the ratio is $10 \%$, which is probably too high, so that our tests are likely to be conservative (we are less likely to reject the null hypothesis that relative marginal productivity equals relative wages).

Summary statistics based on the Computerworld data are reported in Table 2. Between 1989 and 1990, the sample size

6 Source: Table B-44, 1991 Economic Report of the President. 
more than doubled and its composition changed, rendering comparisons before and after the change hazardous. These data reveal a slightly larger (14\%) drop in mean nominal IS budgets than the Informationweek data, from $\$ 133$ million in 1990 to $\$ 114$ million in 1992 . The mean value in the used equipment market of sample firms' computer capital remained roughly constant during 1990-92, at about $\$ 47$ million. The weighted (by net PPE value) mean ratio of the value of computer capital to net PPE value was $1.5 \%$ in both 1990 and 1991. The unweighted mean is about three times as large, indicating that $\left(\mathrm{K}_{1} / \mathrm{K}\right)$ is inversely related to $K$.

During the period 1988-91, computer capital accounted for about $1.8 \%$ of the value of the total capital stock, which implies that $\mathrm{P}_{1} \mathrm{~K}_{1} / \mathrm{P}_{0} \mathrm{~K}_{0}=.018$. As discussed earlier, to obtain the rental value ratio $\left(\mathrm{R}_{1} \mathrm{~K}_{1} / \mathrm{R}_{0} \mathrm{~K}_{0}\right)$ we need to multiply this asset value ratio by $r_{1} / r_{0}$, where $r_{j}(i=0,1)$ is the ratio of asset i's rental price to its asset price. Lau and Tokutsu's analysis suggested that $r_{1} / r_{0}=6$, which implies that $R_{1} K_{1} / R_{0}$ $\mathrm{K}_{0}=10.8 \%$. An estimate of the average ratio of investment in computers to total investment may perhaps serve as a check on the validity of this constructed rental value ratio. Imagine that an economy is in a steady state (zero net investment) and that the prices of output and assets are unchanging. Then $\mathrm{I}_{\mathrm{i}}=\delta_{\mathrm{i}} \mathrm{K}_{\mathrm{i}},\left(\mathrm{I}_{1} / \mathrm{I}_{0}\right)=\left(\delta_{1} / \delta_{0}\right)\left(\mathrm{K}_{1} / \mathrm{K}_{0}\right)$. 
Moreover, given these assumptions and reasonable parameter values, $\left(r_{1} / r_{0}\right) \approx\left(\delta_{1} / \delta_{0}\right)$, so that $\left(I_{1} / I_{0}\right) \approx\left(r_{1} / r_{0}\right)\left(K_{1} / K_{0}\right){ }^{7}$

One would expect the relative rates of investment to be roughly equal to (slightly larger than) the relative rental values. The last column of Table 2 shows weighted (by total investment) average estimates of the ratio of computer equipment purchases to total capital expenditures (I). Computer equipment purchases are calculated as $I_{1}=[(1$ - STAFF - TRAIN $) *$ ISBUD $]$, where STAFF $=$ the fraction of the IS budget devoted to personnel, and TRAIN is the fraction devoted to training. ${ }^{8}$ This figure probably overstates actual computer equipment purchases since it may include purchases of software and lease payments. The average value of $\left(I_{1} / I\right)$ during 1988-91 was about $13 \%$ (implying a mean value of $I_{1} / I_{0}$ of $15 \%$ ), which suggests that our estimate of $10.8 \%$ of the rental value ratio is not unreasonable.

The Informationweek and Computerworld data are examined simultaneously, for a set of "matched observations" (observations for which data were available from both sources)

7 With zero expected asset price changes, $\left(\mathrm{r}_{1} / \mathrm{r}_{0}\right)=(\mathrm{R}+$ $\left.\delta_{1}\right) /\left(\mathrm{R}+\delta_{0}\right)$. With zero inflation, the nominal interest rate $\mathrm{R}$ is equal to the real interest rate, whose long-run average value is perhaps .02 . When $\delta_{1}=.20$ and $\delta_{0}=.05,\left(\mathrm{r}_{1} / \mathrm{r}_{0}\right)=.22 / .07$ $=3.14$, which is not that far from $\left(\delta_{1} / \delta_{0}\right)=4$.

${ }^{8}$ The mean values of these fractions are about $40 \%$ and $3 \%$, respectively. 
in Tables 3 and 4 . The first table reports weighted and unweighted means and standard deviations. The Informationweek estimates of the IS budget and IS employment tend to be higher (by about 10\%) than the corresponding Computerworld figures. In contrast, the Informationweek estimates of IS capital tend to be lower in every year except 1992 (when there is a suspicious jump in the mean). ${ }^{9} \quad$ The standard deviations of the Informationweek $K_{1}$ and $\left(K_{1} / K\right)$ estimates are uniformly lower, often by a substantial amount, consistent with the view that these estimates (based on extremely detailed Computer Intelligence survey data) are more reliable than the Computerworld estimates of the value of computer capital.

Correlation coefficients between Informationweek and Computerworld estimates of IS budget, labor, and capital--both levels and shares (of sales, total employment, and total assets, respectively)--are reported in Table 4 . The correlation between the two IS budget estimates tends to be quite high: it ranges between .85 and .94 . The correlation between the two estimated ratios of IS budget to sales is lower, ranging from .59 to .74 . In the case of IS employment, the pattern is similar, although the correlations are higher: the correlation between $L_{1}$ values is .91 -

9 There is also a suspicious jump in the mean value of the Computerworld $K_{1}$ value in 1991 . Since our production function model includes year dummies, large changes in the annual means per se will not affect our estimates. 
.96, and between ( $\left.\mathrm{L}_{1} / \mathrm{L}\right)$ ratios is .84. Not surprisingly, perhaps, the correlation between alternative $K_{1}$ values is much lower than the correlation between alternative ISBUD and $L_{1}$ values: the mean and median $K_{1}$ correlations are both about .55 . This suggests that estimates of the value of computer capital are less reliable than estimates of the IS budget and of IS employment.

\section{Empirical results}

Estimates of variants of the production function (12) are presented in Table 5. The first line of the table reports a "baseline" regression in which neither capital nor labor is disaggregated into IS- and non-IS components. The coefficients on both total capital and total labor are reasonably well behaved, although their sum (.93) is significantly less than one (suggesting decreasing returns to scale) and the ratio of the capital to the labor coefficient is somewhat larger than one might expect on the basis of relative factor shares. In the next three regressions capital, but not labor, is disaggregated into IS and non-IS components, using the Computerworld estimates, the Informationweek estimates, and an average of the two estimates (when both were available), respectively. In the regression based on Computerworld data on line (2), the coefficient on computer 
capital is positive, large $(.100)$ and highly significant $(t=10.8)$. This indicates that we can easily reject the hypothesis that the marginal product of computer capital (or the rate of return on investment in computers) is zero. To test the hypothesis that the rate of return on computer investment is equal to the rate of return on other investment, we use the statistic $\left(\alpha_{1}-.08 \alpha_{0}\right)$, shown on the right of the table. This is a measure of the difference between the estimated output elasticity of computer capital $\left(\alpha_{1}\right)$ and the expected elasticity under the hypothesis of equal returns $\left(\left(\mathrm{R}_{1} \mathrm{~K}_{1} / \mathrm{R}_{0} \mathrm{~K}_{0}\right) \alpha_{0}=.08 \alpha_{0}\right)$. This statistic is also positive, large, and highly significant. This suggests that there are substantial "excess returns" to investment in computer capital: $\alpha_{1}$ is 2.6 times as large as we would expect to observe if there were zero excess returns $([.100 /(.100-.072)]=2.6)$. The estimates in line (3) based on the Informationweek data are quite similar, although the point estimates of both $\alpha_{1}$ and $\alpha_{0}$ are about 20 percent larger than those in line (2); as a result, the sum of the three elasticities is almost exactly one. In this equation, $\alpha_{1}$ is 3.7 times as large as we would expect to observe under the null hypothesis. The estimates in line (4), based on an average of the two alternative $K_{1}$ values, are almost identical to those in line (2).

These estimates are quite similar to those obtained by Lau and Tokutsu from estimation of a unit cost function from 
aggregate U.S. time-series data ${ }^{10}$; recall that the production function implied by their cost function was

$$
\ln \mathrm{Y}=.072 \ln \mathrm{K}_{1}+.329 \ln \mathrm{K}_{0}+.599 \ln \mathrm{L}
$$

Our estimates of the $K_{1}$ elasticity are $39-69 \%$ larger than theirs, and of the L elasticity $14-18 \%$ smaller. A possible explanation for this is lower relative importance (cost share) of computers at the beginning of the sample period (1960-90) studied by them.

Because IS capital consists entirely of machinery and equipment as opposed to structures (but non-IS capital does not), our finding of higher returns to IS capital is consistent with results reported by De Long and Summers (1991, 445), who found that there "is a much stronger association [across countries]...between growth and [equipment investment than between growth and] any of the other components of investment." They note (p. 447) that "economic historians have seen the richest countries [and enterprises?] as those that were first in inventing and applying capital-intensive technologies, in which machines embody the most advanced technological knowledge."

In the next three regressions labor, but not capital, is disaggregated into IS and non-IS components. Estimates based

10 Although the assumptions of constant returns and cost minimization were imposed in Lau and Tokutsu, and they are not here. 
on the Computerworld IS employment data (for the year 1990 only) are reported in line (5). The coefficient on $L_{1}$ is positive, large, and significant, but the null hypothesis of no excess returns to IS labor cannot be rejected: the t-statistic on the linear combination of parameters $\left(\beta_{1}-.10 \beta_{0}\right)$ is 1.46 . The sample size for the regression based on the Informationweek data, shown in line (6), is almost four times as large. The point estimate of the coefficient on $L_{1}$ is $35 \%$ smaller than it is in eq. (5), but it is estimated much more precisely; the $t$-statistic is 5.4 . The hypothesis of zero excess returns to IS labor is clearly rejected; $\beta_{1}$ is more than twice as large as the value implied by that hypothesis. The estimates based on an average of both sources of data on IS employment, reported in line (7), are very similar to the estimates in the preceding line.

In the last three regressions, both capital and labor are separated into IS and non-IS components. Comparison of eqs. (8) and (5) reveals that, in the relatively small sample based on Computerworld data, distinguishing between IS and non-IS capital lowers the coefficient on IS labor by two-thirds and renders it insignificant. (In contrast, the coefficient on IS capital remains significant, and its magnitude is unaffected, from the disaggregation of labor.) In the regression (9) based on Informationweek data, the coefficients on $K_{1}$ and $L_{1}$ are both positive and highly significant, and they are virtually equal in 
magnitude. Both are about three times as large as we would expect to observe if use of these factors did not yield excess returns. In the final equation (10), based on average values of $K_{1}$ and $L_{1}$ from the two sources, the sum of the $K_{1}$ and $L_{1}$ elasticities is the same--about .21--as in eq. (9), but this eq. assigns more "weight" (and excess returns) to $K_{l}$, and less to $L_{1}$, than eq. (9). ${ }^{11}$ This equation suggests that the computer capital elasticity is over four times as large as one would expect in the absence of excess returns; the computer labor elasticity is about twice as large, but this difference is only marginally significant.

The sum of the IS capital and labor elasticities perhaps provides the most obvious evidence for excess returns to IS expenditure. The last two equations both imply that computer capital and labor jointly contribute, or account for, about 21 percent of output $\left(\alpha_{1}+\beta_{1}=.21\right)$. Our earlier calculations indicated that only about $10 \%$ of both capital and labor income accrue to IS factors.

Loosely speaking, the finding that IS inputs earn excess returns suggests that small changes in IS spending result in large changes in output and productivity. A model developed in a recent paper by Kremer (1993) suggests a mechanism that could possibly underly this. Kremer defines a worker's skill, or

11 In eq. (10), $\beta_{1} /\left(\alpha_{1}+\beta_{1}\right)=.41$; which is very close to the mean ratio of IS labor costs to total IS expenditure. 
quality, level as the probability that he or she does not make a mistake (such as producing defective $\mathrm{O}$-rings) that destroys output (makes the space shuttle explode). Kremer argues that "production consists of many tasks, all of which must be successfully completed for the product to have full value, "so that expected output depends on the joint probability that no worker makes a mistake. He therefore postulates a production function in which the expected output of the firm depends on the product of the skill, or quality, levels of all of the workers in the firm. Kremer shows that the "O-ring production function provides a mechanism through which small differences in worker skill create large differences in productivity and wages." Suppose that information systems have the effect of raising the firm's average skill level--i.e., reducing the probability that workers make mistakes. ${ }^{12}$ Kremer's model implies that the productivity increase resulting from this could be large.

According to the National Science Foundation, the number of "computer specialists employed in industry" increased from

12 In the case of a major financial services company we are studying, information technology is used to perform "trade capture," which reduces errors at their source, and eliminates the need for rework at multiple points down the workflow chain. 
86,800 in 1976 to 345,300 in 1984 to 439,700 in $1986 .{ }^{13}$ The average annual growth rate of $\mathrm{L}_{1}$ during $1976-86$ was $16.2 \%$. During the same period, the growth rate of total employment (and $L_{0}$ ) was about $2 \%$. This implies that, although IS employees accounted for a very small share of total employment even at the end of the period, IS employment growth made a larger contribution to 1976.86 output growth $\left(\beta_{1} * d \ln \mathrm{L}_{1}=\right.$ $.088 * .162=.014)$ than non-IS employment $\left(\beta_{0} * \mathrm{~d} \ln \mathrm{L}_{0}=\right.$ $.458 * .02=.009$ ).

In eq. (10), the elasticity of output with respect to IS employment is $19.2 \%$ as large as the elasticity with respect to non-IS employment $\left(\beta_{1} / \beta_{0}=.088 / .458=.192\right)$. Since the weighted-average value of $\mathrm{L}_{1} / \mathrm{L}_{0}$ is .032 , this implies that the marginal rate of substitution (MRS) between IS and non-IS employees, evaluated at the sample mean, is $6(=.192 / .032)$ : one IS employee can be substituted for six non-IS employees without affecting output. Such an MRS is not inconsistent with evidence from a specific case of computerization of production that we are familiar with. One of the "Baby Bell" local telephone operating companies decided to computerize and automate customer service inquiries. According to internal

13 There were 275,220 IS employees in the 220 firms that reported the number of IS employees in the 1990 Informationweek survey ; 281,371 IS employees in the 251 firms reporting in 1993. 
company documents, the introduction of this technology required the hiring of nine "high-wage" (\$75K) programmers/systems personnel (as well as acquisition of new minicomputers), but would displace 75 "low-wage" $(\$ 42-42.5 \mathrm{~K})$ service representatives. 8.3 non-IS jobs were lost per IS job created. This probably overstates the MRS between IS and non-IS labor, since IS capital is not held constant, but the degree of overstatement may not be very large.

\section{Summary and concluding remarks}

The magnitude, and even the sign, of the impact of computers on output and productivity has been the subject of considerable debate. Some business analysts have asserted that the return on investment in information technology has generally been low, and perhaps even negative. A few econometric studies have provided support for this claim. But a number of others have found that

the output contribution of computers is positive and statistically significant, and may even be quite large. These studies have supported the hypothesis that computer investment yields positive returns, but they have not provided valid tests of the hypothesis that computer investment (like $R \& D$ investment) yields excess returns--returns greater than those earned by other factors. Some 
of these studies examined the period preceding the large increase in the use of computers, and some were based on the manufacturing sector, which is a relatively small user of computers. Although labor costs account for over $40 \%$ of IS budgets, only one previous study has examined the role of IS labor as well as IS capital.

This paper has examined the output contributions of IS capital and IS labor at the firm level during the period 1988-91 throughout the business sector, using two different sources of data on these inputs. We began by establishing some basic facts about the allocation of information technology resources. Expenditure on information systems tends to be about $2.7 \%$ of total revenue, and

the share of IS employment in total employment is about $3.1 \%$. Since the wage rate of IS employees is much higher (on the order of 3 times as high) as that of other workers, the share of IS labor cost in total labor cost is higher, perhaps as high as $10 \%$.

The mean value in the used equipment market of sample firms' computer capital as a percent of their net tangible assets was $1.5 \%$. But because computers have a much higher depreciation rate, and much lower (in fact, negative) rate of asset price appreciation, than other capital, the rental- to asset-price ratio is expected to be six times as high for computers as it is for other assets. This implies that the share of computers in capital 
(rental) income is similar to the share of computers in labor income, about $10 \%$. The sample mean ratio of non-labor IS expenditures to total investment (about 13\% during 1988-91) is consistent with this.

The data suggest that accurate measurement of the replacement cost of computer assets seems to be much more difficult than measurement of IS budgets and employment: the correlation between IS capital values contained in the two surveys is much lower than the correlation between the IS budget and employment values. They also suggest that the Informationweek IS capital data, which are based on an extremely detailed underlying survey and which this study is the first to analyze, are more reliable than the Computerworld estimates.

We estimated production functions in which only capital was disaggregated into IS and non-IS components, only labor was disaggregated, and both inputs were disaggregated. Noise in the computer capital data notwithstanding, the hypothesis of zero returns to computer capital was always decisively rejected by the data. In fact, the estimates indicated that there are substantial "excess returns" to investment in computer capital: its elasticity was $2.6-3.7$ times as large as we would expect to observe if there were zero excess returns (i.e., if the marginal rate of substitution between IS and non-IS capital were equal to the ratio of their rental rates). 
Our estimates are quite similar to those obtained by Lau and Tokutsu from estimation of a unit cost function from aggregate U.S. time-series data, although our estimates of the IS capital elasticity are $39-69 \%$ larger. The finding of excess returns to computer investment is also consistent with De Long and Summers' results concerning equipment investment and growth.

When labor, but not capital, is disaggregated into IS and non-IS components, the hypothesis of zero excess returns to IS labor is clearly rejected; $\beta_{1}$ is more than twice as large as the value implied by that hypothesis. When both capital and labor are separated into IS and non-IS components, it appears that there are excess returns to both IS capital and IS labor, although the size and significance of the excess returns to IS capital is larger.

Several other implications of our estimates may be summarized as follows: (1) computer capital and labor jointly contribute, or account for, about 21 percent of output, although only about $10 \%$ of both capital and labor income accrue to IS factors; (2) although IS employees accounted for a very small share of total employment by 1986 , IS employment growth made a larger contribution to 1976-86 output growth than non-IS employment, due to the very rapid growth (16\% per annum) of IS employment; and (3) the marginal rate of substitution (MRS) between IS and non-IS employees, evaluated at the sample mean, 
is 6: one IS employee can be substituted for six non-IS employees without affecting output. Some anecdotal evidence is consistent with this. 


\section{References}

Barua, Anitesh, Charles Kriebel, and Tridas Mukhopadhyay (1993), "Information Technologies and Business Value: An Analytic and Empirical Investigation," unpub. paper, UT Austin Business School/Carnegie Mellon University GSIA, June.

Baily, Martin Neil, and Robert J. Gordon (1988), "The Productivity

Slowdown, Measurement Issues, and the Explosion of Computer Power,"

Brookings Papers on Economic Activity 19 (2), 347-420.

Berman, Eli, John Bound, and Zvi Griliches (1993), "Changes in the Demand for Skilled Labor within U.S. Manufacturing Industries: Evidence from the Annual Survey of Manufacturing," NBER Working Paper No. 4255, January.

Berndt, Ernst, Catherine Morrison, and Larry Rosenblum (1992), "High-Tech Capital Formation and Labor Composition in U.S. Manufacturing Industries: an Exploratory Analysis," NBER Working Paper No. 4010, March.

Brynjolfsson, Erik, and Lorin Hitt (1993), "Is Information Spending Productive? New Evidence and New Results," unpub. paper, MIT Sloan School, June; forthcoming in the Proceedings of the 14th International Conference on Information Systems.

Choate, Edward T. (1993), "Getting a Return on Your Information Technology Investment," Prism (Arthur D. Little), First Quarter.

Computer Industry Almanac (New York: Simon and Schuster), various issues $1987-92$.

Computerworld (Framingham, MA: CW Publishing, Inc.), various issues $1987-92$. 
De Long, J. Bradford, and Lawrence Summers (1991), "Equipment Investment and Economic Growth," Quarterly Journal of Economics CVI (2), May, 445-502.

Dunne, Timothy, and James Schmitz, Jr. (1992), "Wages, Employer Size-Wage Premia, and Employment Structure: Their Relationship to Advanced-Technology Usage in U.S. Manufacturing Establishments," Manuscript, Federal Reserve Bank of Minneapolis.

Griliches, Zvi, ed. (1992) Output Measurement in the Service Sectors (Chicago: University of Chicago Press).

Hendel, Igal (1992), "The Role of PCs in the Manufacturing Industry," presentation at the NBER Summer Institute, July.

Informationweek (Manhasset, NY: CMP Publications), various issues, 1987-93.

Kremer, Michael (1993), "The O-Ring Theory of Economic Development;" Quarterly Joumal of Economics CVIII (3), August, 551-76.

Krueger, Alan B. (1993), "How Computers Have Changed the Wage

Structure: Evidence From Microdata, 1984-1989," Quarterly Journal

of Economics CVIII (1), 33-60.

Lau, Lawrence, and Ichiro Tokutso (1992), "The Impact of Computer Technology on the Aggregate Productivity of the United States: An Indirect Approach," unpub. paper, Stanford Univ. Dept. of Economics, August.

Lichtenberg, Frank, and Zvi Griliches (1989), "Errors of Measurement in Output Deflators," Journal of Business_and 
Economic Statistics 7, January, 1-9.

Morrison, Catherine, and Emst Berndt (1991), "Assessing the Productivity of Information Technology Equipment in U.S. Manufacturing Industries," NBER Working Paper No. 3582, January.

National Science Foundation (1989), Science and Technology Resources in U.S. Industry (NSF 88-321) (Washington, DC).

New York Times (1993), "Top Executives Seeking More From Technology," Business Section, p. 10, April 25.

Popkin, Joel and Company (1992), "The Impact of Measurement and Analytical Issues in Assessing Industry Productivity and its Relation to Computer Investment" (Washington, DC), October.

Siegel, Donald, and Zvi Griliches (1992), "Purchased Services, Outsourcing, Computers, and Productivity in Manufacturing," in Griliches, Zvi, ed., 429-58. 
Table 1

InformationWeek Data

\begin{tabular}{|c|c|c|c|c|}
\hline \multirow[b]{3}{*}{ Year } & \multirow[b]{3}{*}{$\underline{\mathbf{N}}$} & \multicolumn{3}{|c|}{ Sample means } \\
\hline & & ISBUD & ISBUI & D/SALES \\
\hline & & unwtd. & unwtd. & witd. \\
\hline 1990 & 190 & $\$ 195$ & -- & -- \\
\hline 1991 & 273 & 190 & $2.4 \%$ & $2.6 \%$ \\
\hline 1992 & 277 & 175 & 2.3 & 2.5 \\
\hline 1993 & 245 & 177 & 2.3 & 2.7 \\
\hline
\end{tabular}

Year

$\underline{\mathrm{N}}$

Sample means

$\mathrm{L}_{\mathrm{l}} \quad \mathrm{L}_{\mathrm{l}} / \mathrm{L}$

unwtd. unwtd. witd.

1990

220

$\$ 1251$

$4.3 \% \quad 3.3 \%$

1991

242

1280

$4.2 \quad 3.1$

1992

285

1175

$4.1 \quad 3.1$

1993

251

1121

$\begin{array}{ll}3.6 & 2.9\end{array}$

Note: ISBUD = the firm's information systems budget, in millions of current dollars

ISBUD / SALES = ISBUD as a percent of sales

$\mathrm{L}_{1}=$ number of information systems employees

$\mathrm{L}_{1} / \mathrm{L}=\mathrm{L}_{1}$ as a percent of total employment 


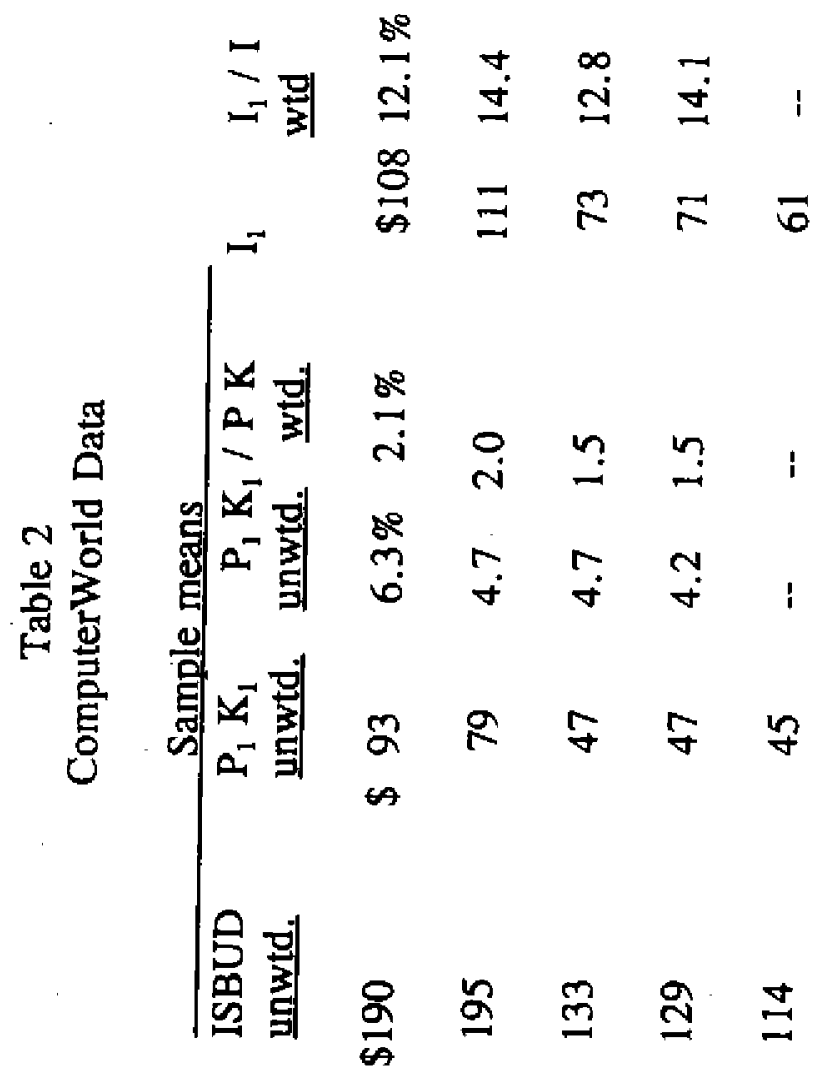

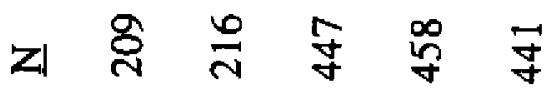

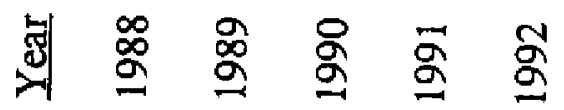


g

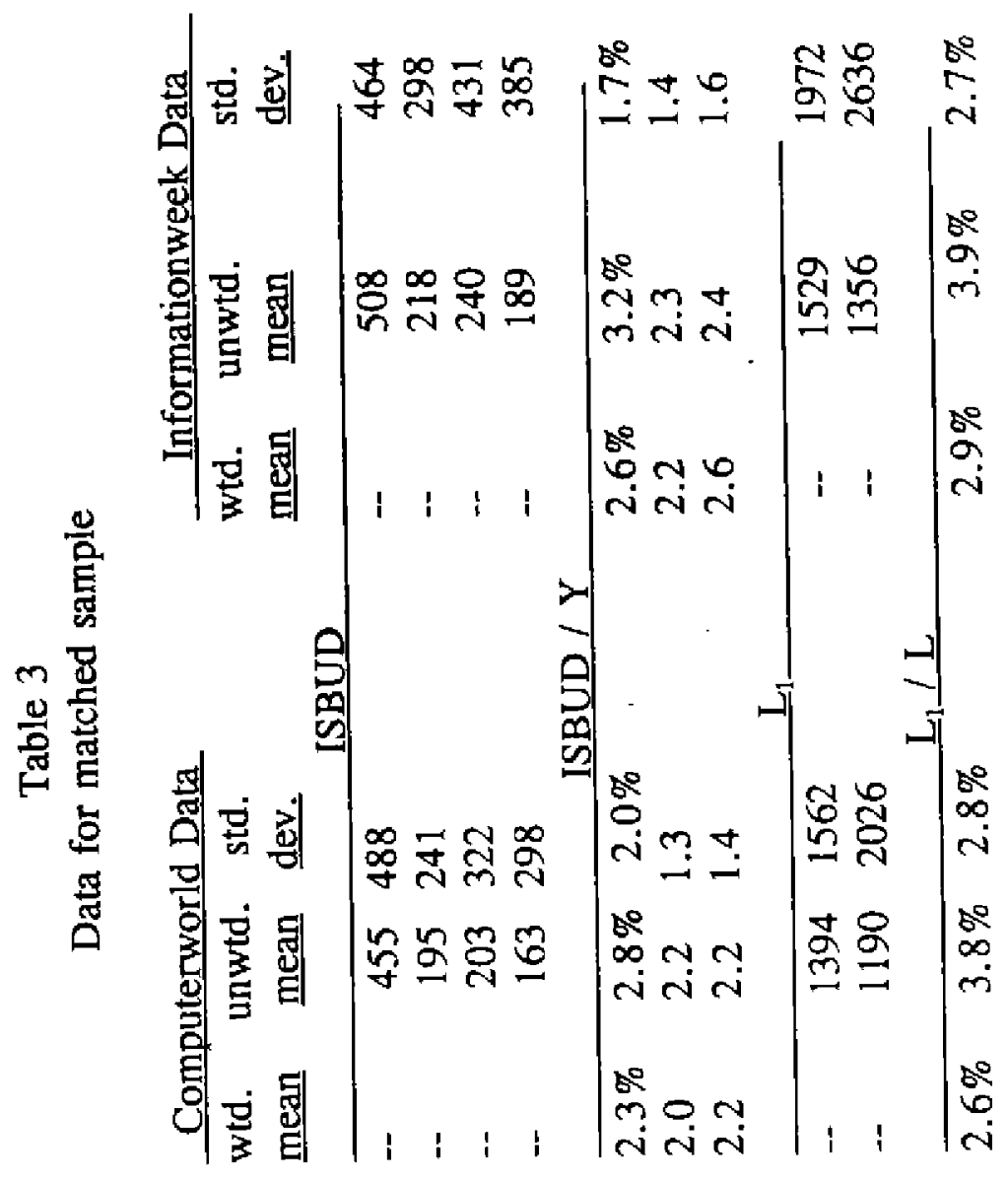

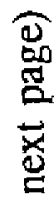

乙

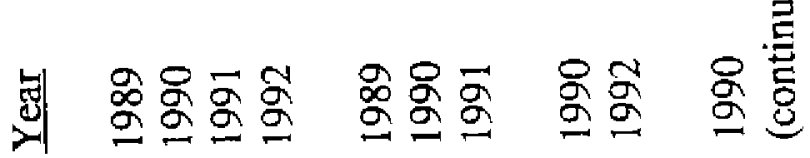




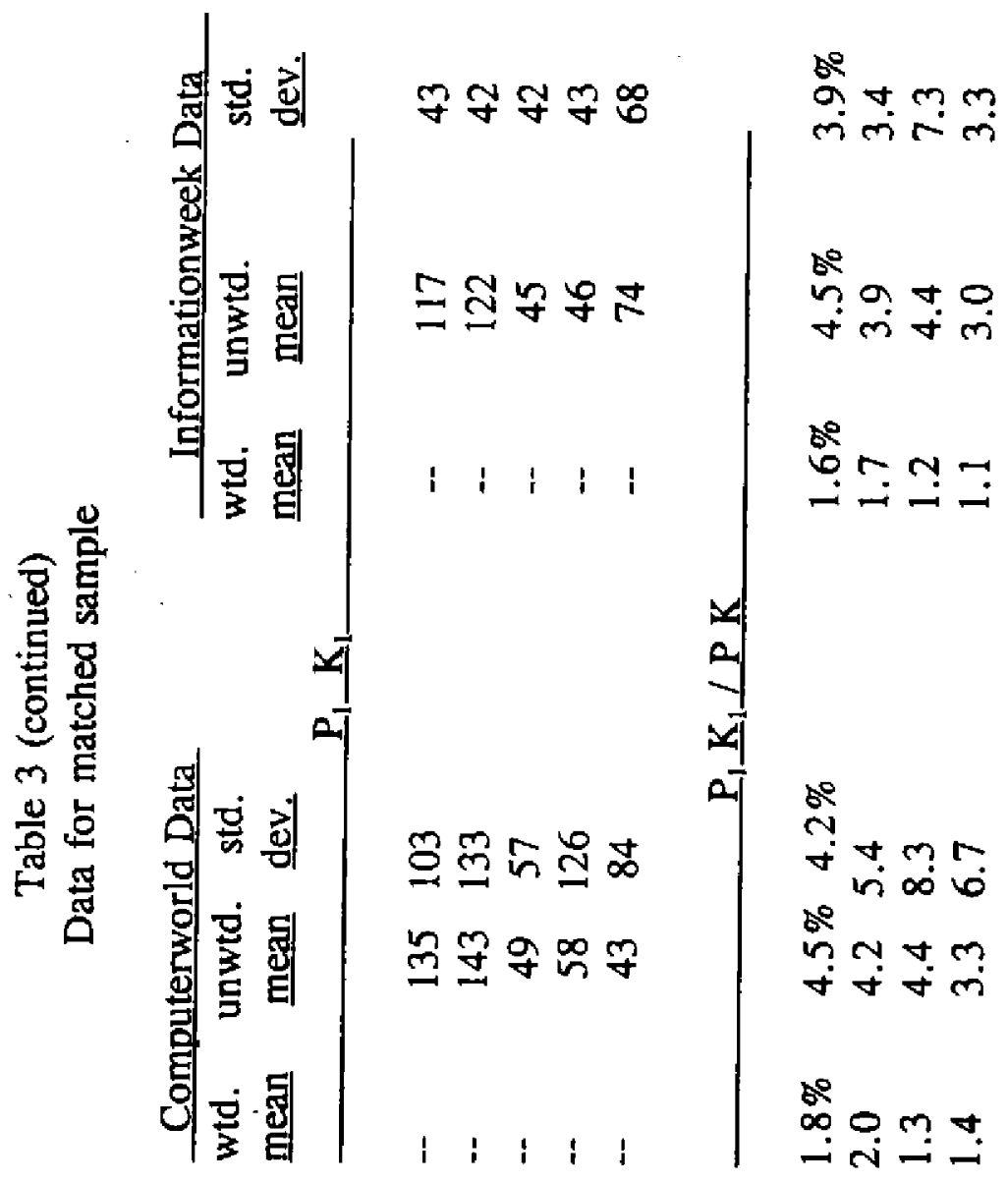

\begin{tabular}{|c|c|}
\hline 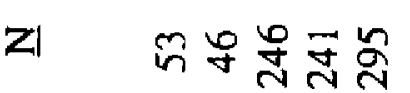 & 同品导志 \\
\hline 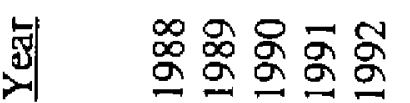 & $\begin{array}{l}\infty \\
\stackrel{2}{a} \\
\stackrel{2}{g}\end{array}$ \\
\hline
\end{tabular}


Table 4

Correlation Coefficients between

Informationweek and Computerworld estimates of

IS Budget, Labor, and Capital

Correlation

$\underline{\text { Year }}$

1989

1990

1991

1992

1990

1992

1988

1989

1990

1991

1992
Correlation

$\underline{\mathrm{N}} \quad$ betw. shares*N

\section{ISBUD}

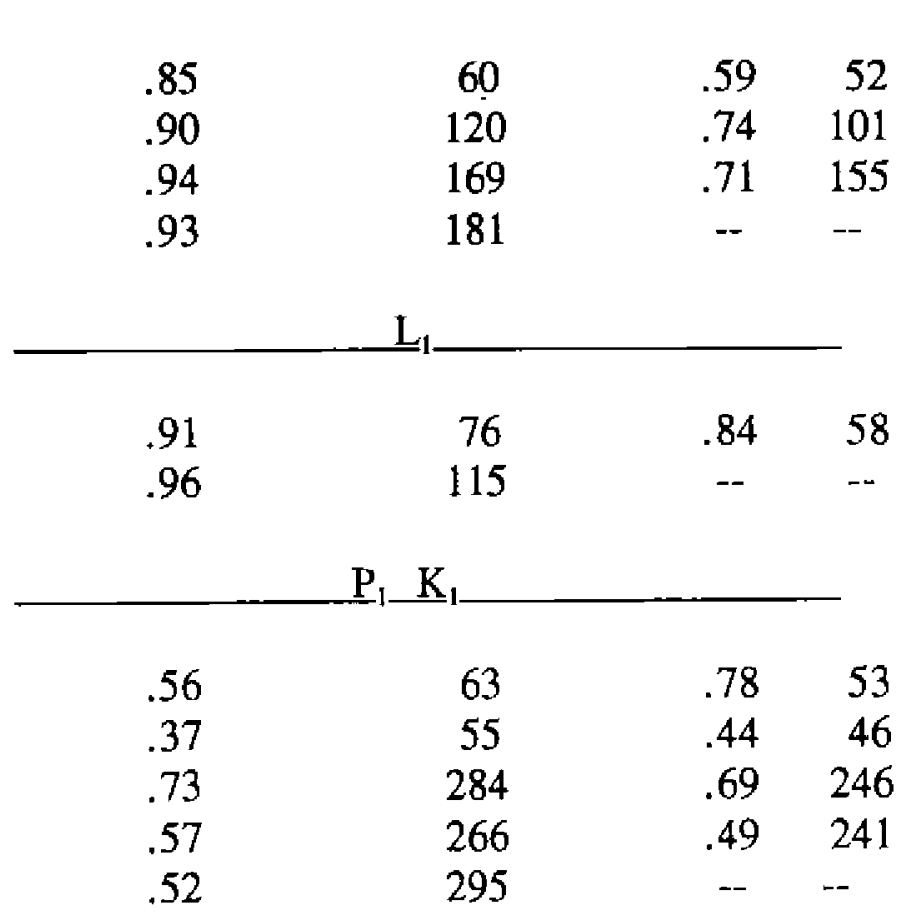

Note: " "Share" is defined as follows:

ISBUD: ISBUD as a percent of sales

$\mathrm{L}_{1}: \mathrm{L}_{1}$ as a percent of total employment

$P_{1} K_{1}: P_{1} K_{1}$ as a percent of value of total assets (PPE) 


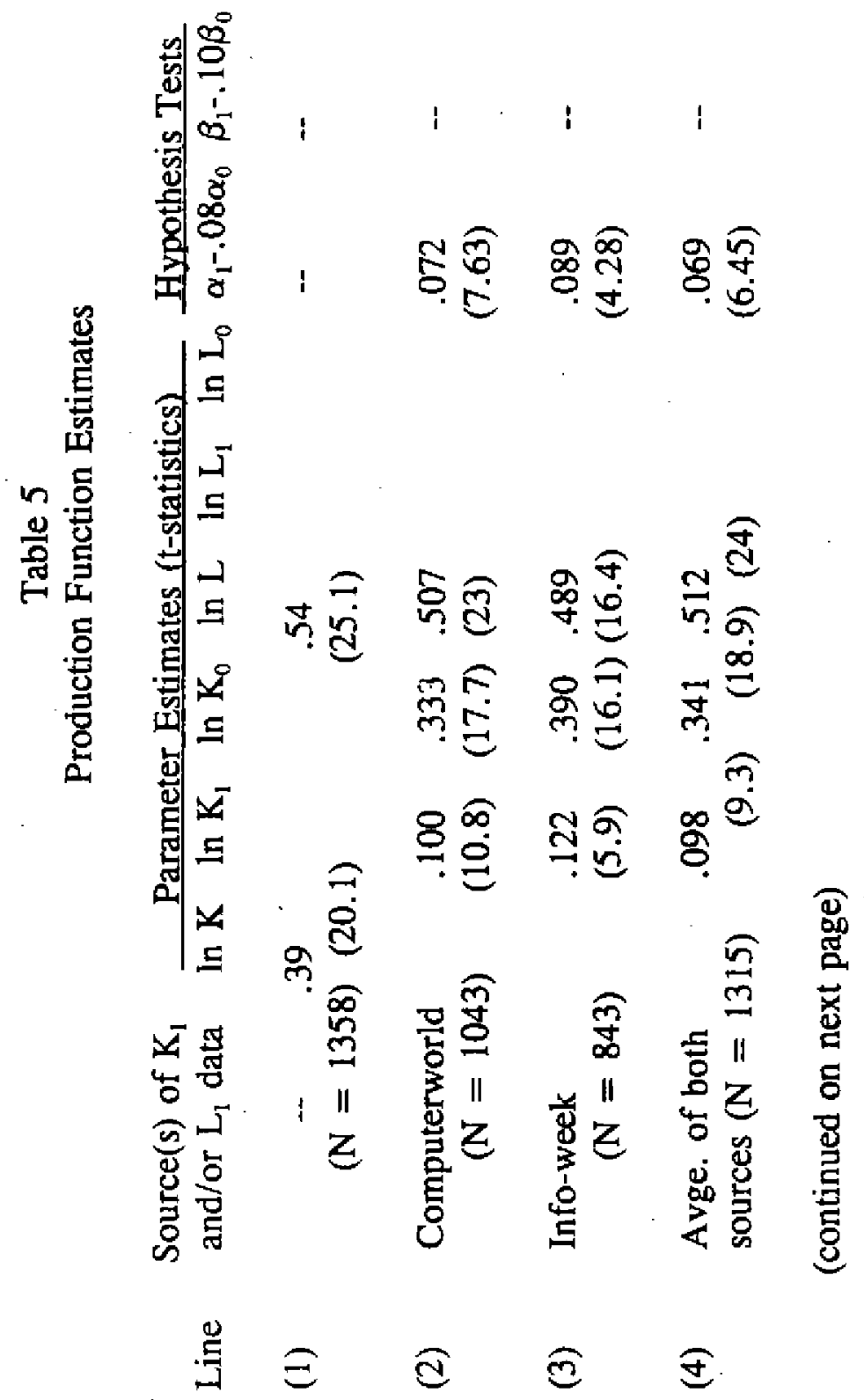




$$
\begin{aligned}
& \text { 包 }
\end{aligned}
$$

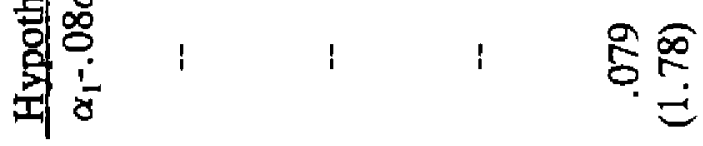

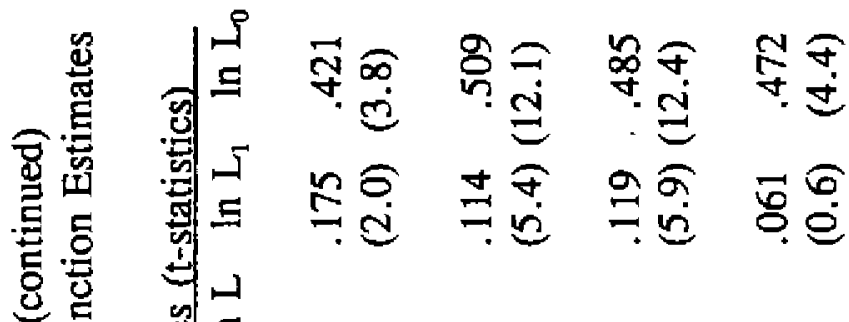

$$
\begin{aligned}
& \text { 记造 }
\end{aligned}
$$

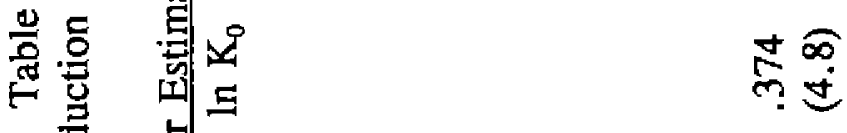

$$
\begin{aligned}
& \text { 总 }
\end{aligned}
$$

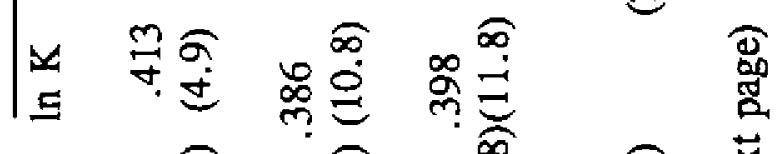

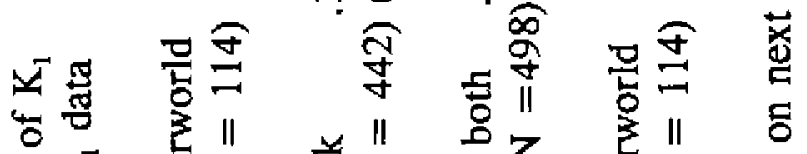

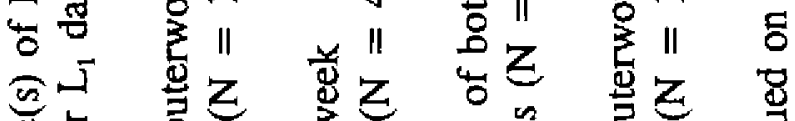

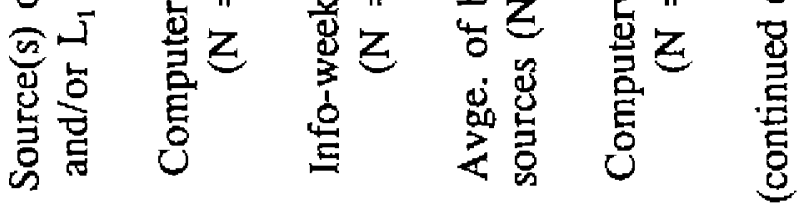

$$
\begin{aligned}
& \text {. }
\end{aligned}
$$




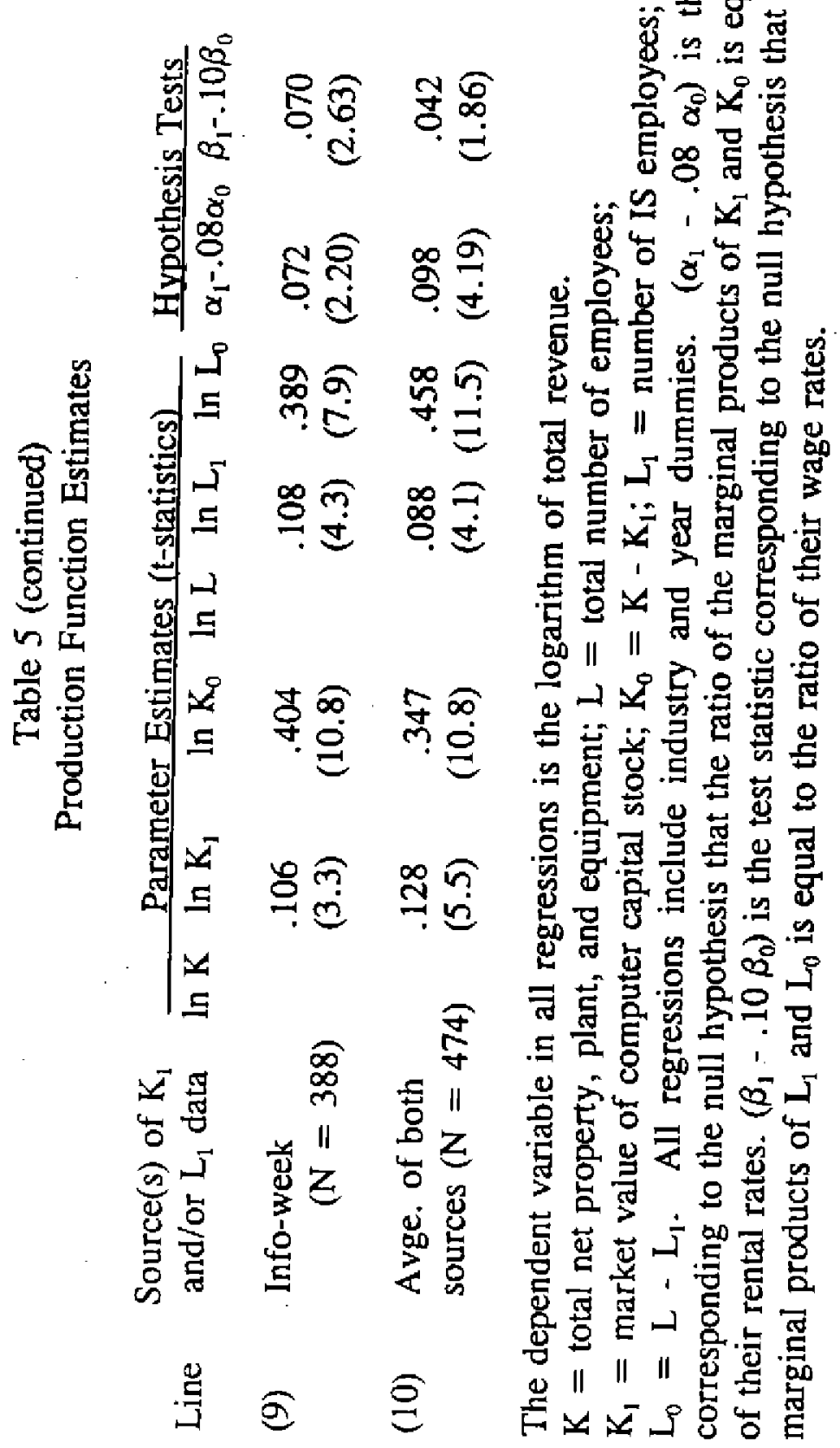

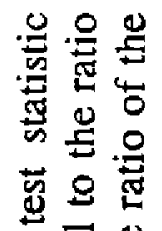

